\title{
ISOLATION, IDENTIFICATION AND COMPARISON OF SOME PROPERTIES OF LACTOBACILLUS DELBRUECKII SUBSP. BULGARICUS STRAINS FROM TRADITIONAL BULGARIAN AND ITALIAN YOGURTS
}

\author{
Yulian D. Tumbarski ${ }^{1 \bowtie}$, Velichka B. Yanakieva ${ }^{1}$, Rositsa S. Denkova-Kostova ${ }^{2}$, Zapryana R. \\ Denkova ${ }^{1}$ \\ ${ }^{I}$ Department of Microbiology, University of Food Technologies, Plovdiv, Bulgaria \\ ${ }^{2}$ Department of Biochemistry and Molecular Biology, University of Food Technologies, Plovdiv, Bulgaria \\ tumbarski@abv.bg
}

https://doi.org/10.34302/crpjfst/2021.13.1.4

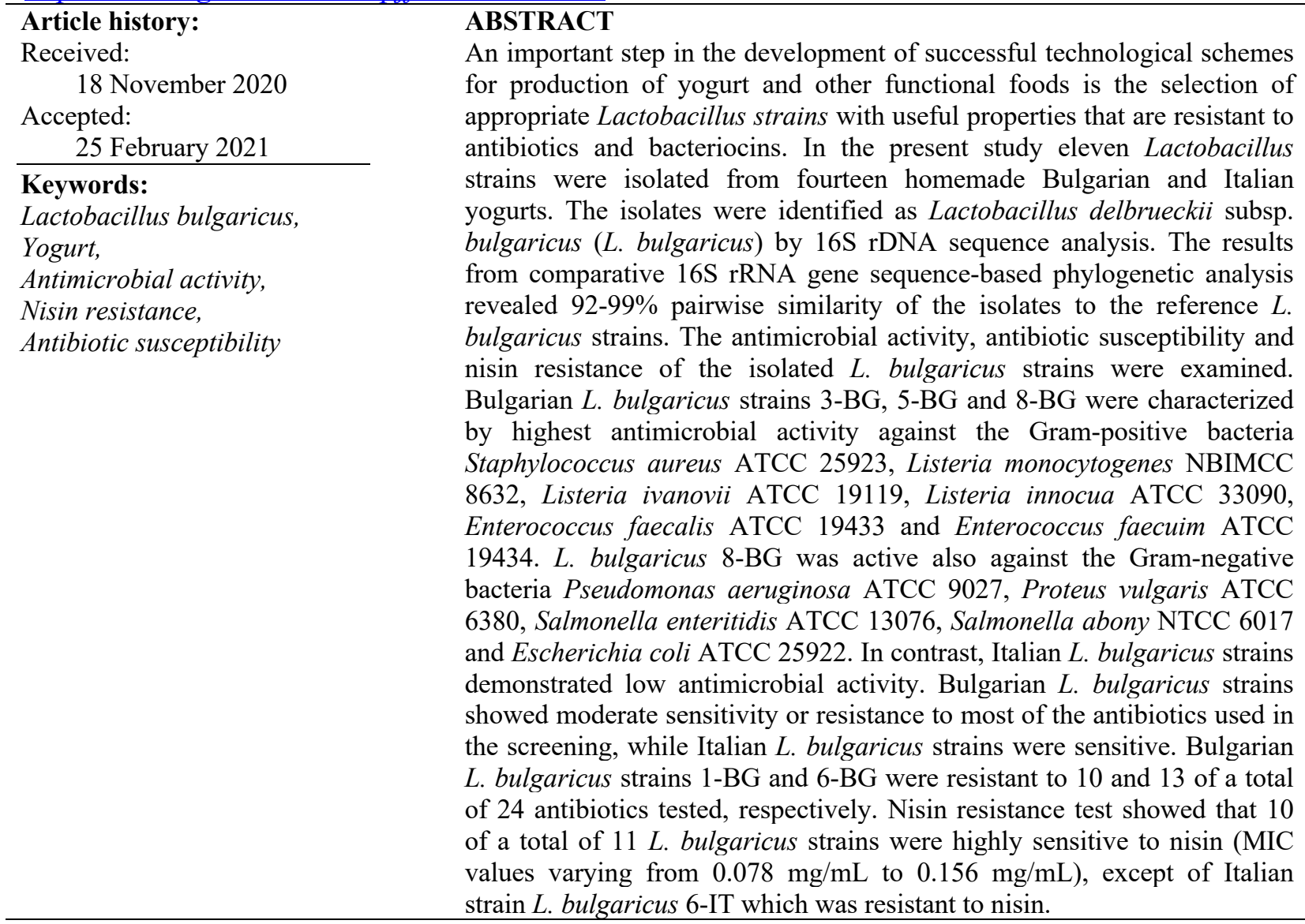

\section{Introduction}

Lactobacilli are lactic acid bacteria (LAB) that have been successfully used for many centuries in fermentation processes in the production of various foods. The life of modern people and associated "diseases of the 21-st century" have focused the scientific and commercial interests on the use of lactobacilli in a number of functional foods and probiotic products that have a positive impact on intestinal microflora, thus exert beneficial effect on the physiological status. Nowadays, they are widely accepted as useful component of the food chain, with a substantial role in 
maintaining a healthy balance and preventing diseases in humans and animals.

Lactobacillus delbrueckii subsp. bulgaricus (Lactobacillus bulgaricus), isolated and described for a first time by the Bulgarian physician Dr. Stamen Grigoroff (1905), is the most economically important representative of the heterogeneous group of LAB with global application in the manufacture of fermented and functional foods, in particular yogurt. One of the most popular varieties of yogurt is the traditional Bulgarian yogurt, which has been consumed for millennia as a traditional food on the Balkans, known also as sour milk or "kiselo mlyako" due to its specific taste. Yogurt is recognized as a nutritious, natural and safe component of the healthy diet, which has beneficial effects on the gastrointestinal microflora and underlies the concept of probiotic foods. The benefits for human health from the consumption of yogurt are well known, and in recent years numerous studies have proven its therapeutic effects on various disorders (Adolfsson et al., 2004; McKinley, 2005; Fisberg and Machado, 2015).

The selection of appropriate Lactobacillus strains with useful properties is of paramount importance in the development of successful technological schemes in the dairy industry. Lactobacillus strains used as starter cultures or in composition of probiotic foods, should be carefully selected not only for their contribution to the organoleptic properties of the product (aroma, taste and texture), but also for their biological activities. In addition to the generally accepted requirement to be "generally recognized as safe" (GRAS), the probiotic strains must meet some other basic criteria related to their survival in vivo and probiotic role, such as resistance to the conditions in the gastrointestinal tract (Chen et al., 2017), adhesion to the intestinal epithelial cells, antimicrobial activity (Silva et al., 2020), and resistance to antibiotics (Havenaar et al., 1992; Amara et al., 2019).

The use of L. bulgaricus strains and their metabolites as biopreservatives in order to improve the shelf-life of various foods requires selection of strains that possess high antimicrobial activity (Mohammed et al., 2013). Another desired feature in the selection of L. bulgaricus strains is their resistance to antibiotics. The susceptibility of L. bulgaricus to different antibiotics used in the clinical practice for treatment of intestinal and other infections is considered undesirable, and in these cases antibiotic therapy reduces the effectiveness of probiotics and functional foods. On the other hand, the natural resistance of some L. bulgaricus strains may also have a negative side, as they can serve as sources of genes responsible for antibiotic resistance to be genetically transferred to the pathogenic bacteria, thus to threat human and animal health. Therefore, before including the lactobacilli strains in the composition of starter cultures or probiotic products, it is necessary to check whether these strains do not have transferable genes for antibiotic resistance (Danielsen and Wind, 2003; Karapetkov et al., 2011).

The application of some LAB bacteriocins (nisin) as biopreservatives in fermented products to prolong the shelf-life and control the pathogenic and spoilage microorganisms may have a negative impact on the strains in the starter culture and lactic acid fermentation. In this regard, the selection of L. bulgaricus strains resistant or weakly sensitive to nisin is also important for the technological process in the manufacture of quality fermented products.

Therefore, the aim of the present study was to isolate and identify $L$. bulgaricus strains from traditional Bulgarian and Italian yogurts, and to evaluate and compare some important properties of the strains such as antimicrobial activity, nisin resistance and antibiotic susceptibility.

\section{Materials and methods}

\subsection{Materials}

\subsubsection{Yogurts}

Fourteen samples of homemade yogurts (eight Bulgarian and six Italian) were used in the study. 


\subsubsection{Test microorganisms}

Six Gram-positive bacteria (Staphylococcus aureus ATCC 25923, Listeria monocytogenes NBIMCC 8632, Listeria innocua ATCC 33090, Listeria ivanovii ATCC 19119, Enterococcus faecalis ATCC 19433, Enterococcus faecuim ATCC 19434) and six Gram-negative bacteria (Pseudomonas aeruginosa ATCC 9027, Proteus vulgaris ATCC 6380, Salmonella enteritidis ATCC 13076, Salmonella abony NTCC 6017, Escherichia coli ATCC 25922, Klebsiella sp. clinical isolate) from the collection of the Department of Microbiology, University of Food Technologies, Plovdiv, Bulgaria were used in the antimicrobial screening.

\subsubsection{Nisin}

Nisin produced by Lactococcus lactis subsp. lactis - 2.5\% (Sigma-Aldrich, USA), containing 1000000 IU active substance/g was used.

\subsubsection{Culture media}

Milk. Milk was prepared by the following prescription: $80 \mathrm{~g}$ of skim milk was dissolved in $1 \mathrm{~L}$ of deionized water, and then autoclaved at $112{ }^{\circ} \mathrm{C}$ for $45 \mathrm{~min}$.

LAPTg10 broth. LAPTg10 broth was prepared by the manufacturer's (Laboratorios Conda S.A., Spain) prescription: $45 \mathrm{~g}$ of LAPTg10-solid substance mixture (containing $15 \mathrm{~g}$ peptone, $10 \mathrm{~g}$ yeast extract, $10 \mathrm{~g}$ tryptone and $10 \mathrm{~g}$ glucose) was dissolved in $1 \mathrm{~L}$ of deionized water. $\mathrm{pH}$ was adjusted to 6.6-6.8, and then $1 \mathrm{~mL}$ Tween 80 (Sigma-Aldrich) was added. The medium was autoclaved at $121{ }^{\circ} \mathrm{C}$ for $20 \mathrm{~min}$.

LAPTg10 agar. This medium was prepared by the following prescription: $45 \mathrm{~g}$ of LAPTg10-solid substance mixture (Laboratorios Conda S.A.) was dissolved in $1 \mathrm{~L}$ of deionized water. The final $\mathrm{pH}$ was adjusted to 6.6-6.8, and then $1 \mathrm{~mL}$ Tween 80 (SigmaAldrich) and $15 \mathrm{~g}$ of agar (Sigma-Aldrich) were added. The medium was autoclaved at $121{ }^{\circ} \mathrm{C}$ for $20 \mathrm{~min}$.

Luria-Bertani agar medium supplemented with glucose (LBG agar). LBG agar was prepared by the manufacturer's (Laboratorios
Conda S.A.) prescription: $50 \mathrm{~g}$ of LBG-solid substance mixture (containing $10 \mathrm{~g}$ tryptone, 5 g yeast extract, $10 \mathrm{~g} \mathrm{NaCl}, 10 \mathrm{~g}$ glucose and 15 $\mathrm{g}$ agar) was dissolved in $1 \mathrm{~L}$ of deionized water. The final $\mathrm{pH}$ was adjusted to 7.5 , and then medium was autoclaved at $121^{\circ} \mathrm{C}$ for 20 min.

de Man, Rogosa and Sharpe (MRS) agar. This medium was prepared by the manufacturer's (Merck, Germany) prescription: $55.2 \mathrm{~g}$ of MRS broth (containing $10 \mathrm{~g}$ peptone, $5 \mathrm{~g}$ yeast extract, $10 \mathrm{~g}$ beef extract, $20 \mathrm{~g}$ glucose, $2 \mathrm{~g}$ potassium phosphate, $5 \mathrm{~g}$ sodium acetate, $0.2 \mathrm{~g}$ magnesium sulphate, $0.05 \mathrm{~g}$ manganese sulfate, $1 \mathrm{~g}$ Tween 80 and $2 \mathrm{~g}$ ammonium citrate) was dissolved in $1 \mathrm{~L}$ of deionized water. The final $\mathrm{pH}$ was adjusted to 6.4 , and then $15 \mathrm{~g}$ of agar (Sigma-Aldrich) was added. The medium was autoclaved at $121{ }^{\circ} \mathrm{C}$ for $15 \mathrm{~min}$.

Modified de Man, Rogosa and Sharpe (mMRS) agar. The modified MRS agar medium was prepared by the following prescription: $55.2 \mathrm{~g}$ of MRS broth (Merck) and $0.05 \mathrm{~g}$ L-cysteine (Merck) were dissolved in 1 $\mathrm{L}$ of deionized water. The final $\mathrm{pH}$ was adjusted to 6.4, and then $15 \mathrm{~g}$ of agar (SigmaAldrich) was added. The medium was autoclaved at $121^{\circ} \mathrm{C}$ for $15 \mathrm{~min}$.

Modified skim milk (MSM) agar. This medium was prepared by the manufacturer's (Himedia ${ }^{\circledR}$, India) prescription: $24.5 \mathrm{~g}$ of solid substance mixture (containing $5 \mathrm{~g}$ tryptone, 2.5 $\mathrm{g}$ yeast extract, $1 \mathrm{~g}$ glucose monohydrate, $1 \mathrm{~g}$ skim milk powder and $15 \mathrm{~g}$ agar) was dissolved in $1 \mathrm{~L}$ of deionized water. The final $\mathrm{pH}$ was adjusted to 7.0, and the medium was autoclaved at $121{ }^{\circ} \mathrm{C}$ for $15 \mathrm{~min}$.

\subsection{Methods}

\subsubsection{Isolation and cultivation of the strains}

Samples from yogurts were first propagated in milk ( $1 \mathrm{~mL}$ sample $+9 \mathrm{~mL}$ milk) and incubated at $42{ }^{\circ} \mathrm{C}$ for $3-4 \mathrm{~h}$ (until coagulation). Then samples were streaked on LAPTg10 agar medium, and the Petri plates (d=90 mm; Gosselin ${ }^{\mathrm{TM}}$, France) were incubated at $37^{\circ} \mathrm{C}$ for $48 \mathrm{~h}$. Single colonies were cut and 
transferred into $2 \mathrm{~mL}$ of LAPTg10 broth, stirred by vortex $\mathrm{V}-1$ plus (Biosan, Latvia) for 5-10 s, and cultured at $37{ }^{\circ} \mathrm{C}$ for $48 \mathrm{~h}$. Next, 1 $\mathrm{mL}$ of the biomass was transferred into $5 \mathrm{~mL}$ of LAPTg10 broth and incubated under identical conditions, then stored at $4{ }^{\circ} \mathrm{C}$ for further analyses. The cellular morphology of the isolated strains was determined by microscopic observation of colored smears. The colony morphology of the isolates was described by microscopic observation of single colonies grown on LAPTg10 agar, MRS agar, mMRS agar and MSM agar media.

\subsubsection{Isolation of total $\mathrm{DNA}$}

The isolation of DNA was performed by the method of Delley et al. (1990).

\subsection{3. $16 S \mathrm{rDNA}$ amplification}

$16 \mathrm{~S}$ rDNA of the isolates was amplified using the universal primers $27 \mathrm{~F}$ (5'AGAG TTTGATCMTGGCTCAG3') and 1492R (5'TACGGYTACCTTGTTACGACTT3')

according to the method of Lane (1991). The amplification program included: denaturation $95{ }^{\circ} \mathrm{C}$ for $3 \mathrm{~min} ; 40$ cycles $-93{ }^{\circ} \mathrm{C}$ for $30 \mathrm{~s}, 55$ ${ }^{\circ} \mathrm{C}$ for $60 \mathrm{~s}, 72{ }^{\circ} \mathrm{C}$ for $2 \mathrm{~min}$; final elongation $72{ }^{\circ} \mathrm{C}$ for $5 \mathrm{~min}$.

\subsubsection{Purification of the product of the PCR- reaction from $T A E$ agarose gel}

The purification of $16 \mathrm{~S}$ rDNA was conducted using a DNA-purification kit in a Microspin $^{\mathrm{TM}}$ column following the standard protocol (Denkova et al., 2012).

\subsubsection{Sequencing of the $16 \mathrm{~S}$ rRNA gene}

The partial sequencing of the $16 \mathrm{~S}$ rRNA gene with two universal primers $(27 \mathrm{~F}$ and 1492R) was implemented according to the method of Sanger et al. (1977) at "Macrogen Europe Laboratory", The Netherlands.

The entire sequence of the 16S rRNA gene was obtained using the CLC Sequence Viewer software, and the resulting whole sequence was compared with the on-line database sequences via the BLASTn algorithm. Thus, the studied strains were identified to the species level with the corresponding confidence level.

\subsubsection{Antimicrobial activity}

The antimicrobial activity of $L$. bulgaricus strains was determined by the agar well diffusion method. The test bacteria were cultivated on LBG agar medium at $37^{\circ} \mathrm{C}$ for 24 h. To prepare bacterial inocula, a small amount of biomass of each test microorganism was suspended in $5 \mathrm{~mL}$ of sterile $0.5 \% \mathrm{NaCl}$, and then vortexed (V-1 plus, Biosan) for 5-10 s. The number of viable cells in each bacterial inoculum was determined using the counting chamber Thoma (Poly-Optik GmbH, Germany), and the final concentration was adjusted to $1.0 \times 10^{8} \mathrm{cfu} / \mathrm{mL}$. Next, bacterial suspensions were inoculated in preliminarily melted and tempered at $45-48{ }^{\circ} \mathrm{C}$ LAPTg10 agar media. The inoculated media were transferred in quantity of $18 \mathrm{~mL}$ in sterile Petri plates (Gosselin ${ }^{\mathrm{TM}}$ ) and allowed to harden. Then six wells $(\mathrm{d}=6 \mathrm{~mm})$ per plate were cut.

L. bulgaricus strains (cultured in LAPTg10 broth at $37^{\circ} \mathrm{C}$ for $48 \mathrm{~h}$ ) were pippeted into the agar wells in quantity of $60 \mu \mathrm{L}$. As a control, the antibiotic Ampicillin $(10 \mathrm{mg} / \mathrm{mL})$ was used. The Petri plates (Gosselin ${ }^{\mathrm{TM}}$ ) were incubated at identical conditions. The antimicrobial activity was evaluated by measuring the diameter of the inhibition zones around the wells at the 24-th and 48-th $\mathrm{h}$ after incubation. The results were interpreted as follows: high antimicrobial activity - inhibition zones of $18 \mathrm{~mm}$ or more; moderate antimicrobial activity - inhibition zones from 12 to $18 \mathrm{~mm}$; low antimicrobial activity - inhibition zones under $12 \mathrm{~mm}$ (Tumbarski et al., 2018a).

\subsubsection{Nisin resistance test and minimal inhibitory concentration}

Nisin resistance and minimal inhibitory concentration (MIC) of nisin were determined by the dilution method. Two-fold serial dilutions of nisin in sterile distilled water, ranging from $10 \mathrm{mg} / \mathrm{mL}$ to $0.0049 \mathrm{mg} / \mathrm{mL}$ were prepared. $60 \mu \mathrm{L}$ of dilution was pipetted in wells cut in LAPTg10 agar media inoculated with each L. bulgaricus strain. The Petri plates $\left(\right.$ Gosselin ${ }^{\mathrm{TM}}$ ) were incubated at $37^{\circ} \mathrm{C}$ for $48 \mathrm{~h}$. The MIC values were determined as the lowest concentration of nisin inhibiting completely the growth of each L. bulgaricus strain around the agar well (Tumbarski et al., 2017). 


\subsubsection{Antibiotic susceptibility test}

Antibiotic susceptibility test was performed by in vitro disc diffusion method of Bauer et al. (1966) with impregnated paper discs of 24 antibiotics (Bul Bio - NCIPD Ltd., Bulgaria). The strain suspensions $(0.1 \mathrm{~mL})$ were spread plated on LAPTg10 agar medium, and then four discs of different antibiotics per Petri plate (Gosselin ${ }^{\mathrm{TM}}$ ) were put on the surface of the agar medium. The plates were incubated at $37{ }^{\circ} \mathrm{C}$ for $48 \mathrm{~h}$. Zones of inhibition were measured and recorded at 24-th and 48-th h of incubation. Strains with no inhibition zones were considered resistant; with inhibition zones from 7 to $16 \mathrm{~mm}$ - intermediate sensitive; with zones $>16 \mathrm{~mm}-$ sensitive.

\subsubsection{Statistical analysis}

Data from triplicate experiments for the antimicrobial activity were processed with MS Office Excel 2010 software, using statistical functions to determine the standard deviation $( \pm \mathrm{SD})$, and maximum estimation error at significance level $\alpha \dot{\alpha}<0.05$.

\section{Results and discussions}

\subsection{Strain isolation, cellular and colony morphology}

In the present study, six L. bulgaricus strains were isolated from eight traditional Bulgarian yogurts (1-BG, 3-BG, 5-BG, 6-BG, 7-BG and 8-BG) and five L. bulgaricus strains were isolated from six Italian yogurts (1-IT, 3IT, 4-IT, 5-IT and 6-IT).
The microscopic observation of colored smears showed that all isolated strains possessed the typical cellular morphology for L. bulgaricus - Gram-positive, rod shaped with rounded ends $(0.5-0.8 \mu \mathrm{m} \times 2-9 \mu \mathrm{m})$ or filamentous $(0.5-0.8 \mu \mathrm{m} \times 20-25 \mu \mathrm{m})$ arranged singly, in short or longer chains (figures not provided), which depends on the age of the culture and the composition of the growth medium (Teixeira, 2014). The colony morphology of the isolates was determined by microscopic observation of single colonies. To study the influence of the medium composition on L. bulgaricus colony characteristics, the strains were cultured on different agar media used for isolation, enumeration and differentiation of lactobacilli from milk, yogurt, cheese, and other fermented milk products LAPTg10, MRS, mMRS and MSM. The colonies of all isolated strains exhibited the typical characteristics for $L$. bulgaricus colonies - 1-6 $\mathrm{mm}$ in diameter, whitish, round or irregular shaped, flat profile, with or without dot-like center, serrated edges, rough surface, and soft texture, similar to those observed by Tabasco et al. (2007), Nwamaioha and Ibrahim (2018), and Oyeniran et al. (2020). In the present study, L. bulgaricus strains were affected by the type and composition of the agar media, and formed colonies with different morphology parameters (mainly size and shape), or did not grow on all agar media. Good growth of all strains was observed only on LAPTg10 agar medium (Table 1).

Table 1. Colony morphology of L. bulgaricus strains on different agar media for lactobacilli

\begin{tabular}{|l|l|c|l|}
\hline Strain & Culture medium & \multicolumn{1}{|c|}{$\begin{array}{c}\text { Colony } \\
\text { morphology }\end{array}$} & \multicolumn{1}{c|}{$\begin{array}{c}\text { Colony } \\
\text { description }\end{array}$} \\
\hline \multirow{3}{*}{ 1-BG } & LAPTg10 agar & & $\begin{array}{l}1-2 \mathrm{~mm} \text { in diameter, whitish, flat, } \\
\text { irregular shaped (snowflake- } \\
\text { like), serrated edges, rough } \\
\text { surface, soft texture }\end{array}$ \\
\cline { 3 - 5 } & MRS agar & & No growth \\
\cline { 2 - 4 } & mMRS agar & & No growth \\
\cline { 2 - 4 } & MSM agar & & No growth \\
\hline
\end{tabular}




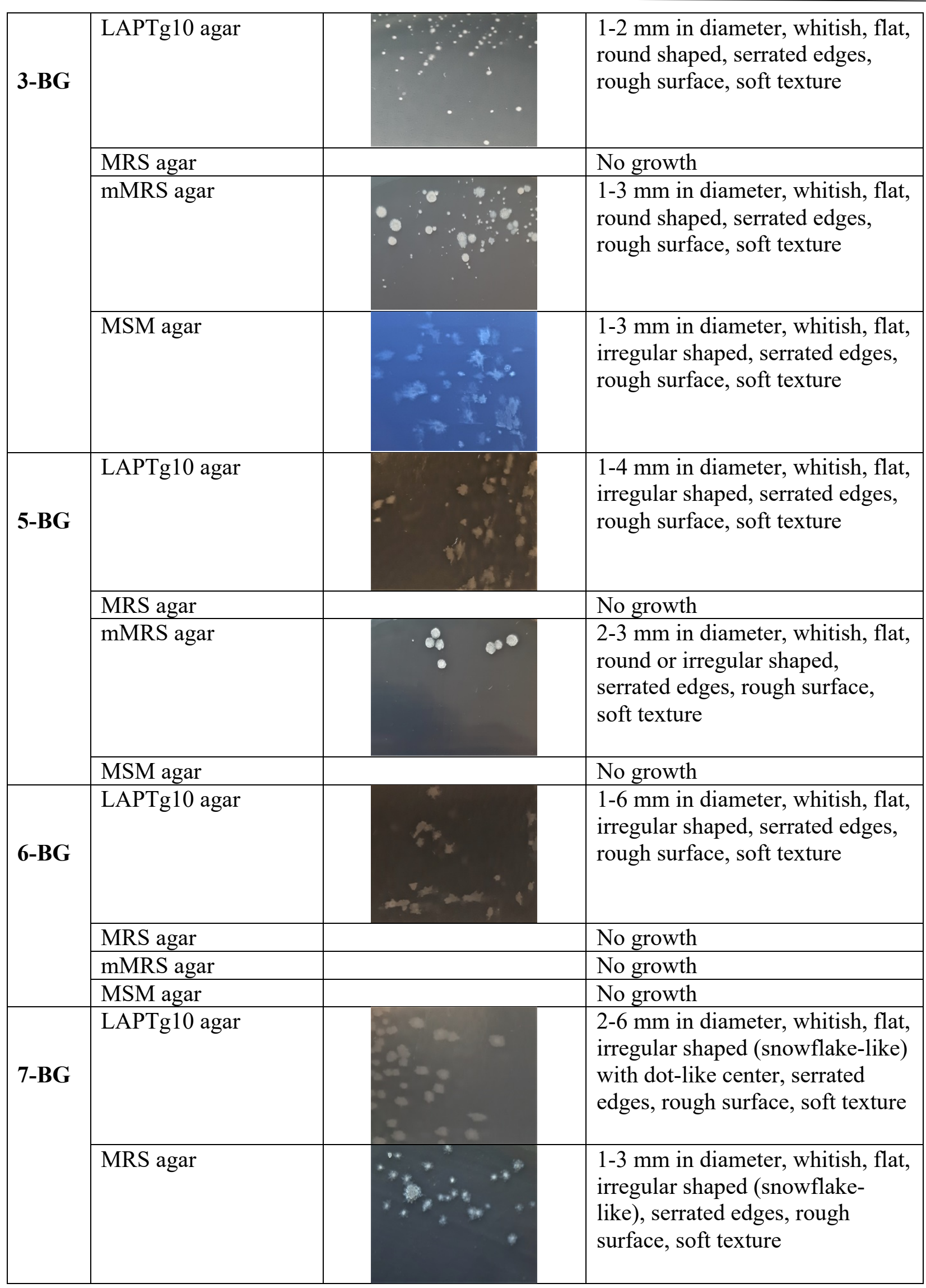




\begin{tabular}{|c|c|c|c|}
\hline & mMRS agar & $y^{2}+x^{2}$ & $\begin{array}{l}\text { 1-5 mm in diameter, whitish, flat, } \\
\text { irregular shaped (snowflake- } \\
\text { like), serrated edges, rough } \\
\text { surface, soft texture }\end{array}$ \\
\hline & MSM agar & 38 & $\begin{array}{l}\text { 1-2 mm in diameter, whitish, flat, } \\
\text { irregular shaped (snowflake- } \\
\text { like), serrated edges, rough } \\
\text { surface, soft texture }\end{array}$ \\
\hline \multirow[t]{4}{*}{ 8-BG } & LAPTg10 agar & & $\begin{array}{l}\text { 1-2 mm in diameter, whitish, flat, } \\
\text { irregular shaped (snowflake- } \\
\text { like), serrated edges, rough } \\
\text { surface, soft texture }\end{array}$ \\
\hline & MRS agar & & No growth \\
\hline & mMRS agar & & No growth \\
\hline & MSM agar & 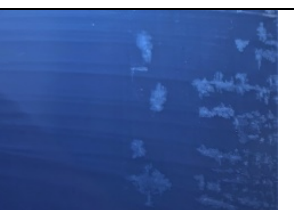 & $\begin{array}{l}\text { 1-5 mm in diameter, whitish, flat, } \\
\text { irregular shaped (snowflake- } \\
\text { like), serrated edges, rough } \\
\text { surface, soft texture }\end{array}$ \\
\hline \multirow[t]{4}{*}{ 1-IT } & LAPTg10 agar & 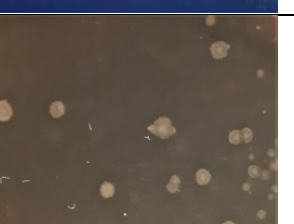 & $\begin{array}{l}\text { 1-4 mm in diameter, whitish, flat, } \\
\text { irregular shaped (snowflake-like) } \\
\text { with dot-like center, serrated } \\
\text { edges, rough surface, soft texture }\end{array}$ \\
\hline & MRS agar & & $\begin{array}{l}\text { 1-3 mm in diameter, whitish, flat, } \\
\text { round or irregular shaped with } \\
\text { dot-like center, serrated edges, } \\
\text { rough surface, soft texture }\end{array}$ \\
\hline & mMRS agar & 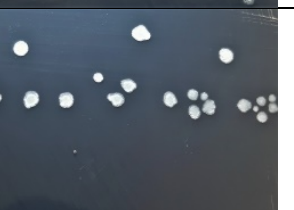 & $\begin{array}{l}\text { 1-4 mm in diameter, whitish, flat, } \\
\text { round or irregular shaped, } \\
\text { serrated edges, rough surface, } \\
\text { soft texture }\end{array}$ \\
\hline & MSM agar & & $\begin{array}{l}1-2 \mathrm{~mm} \text { in diameter, whitish, flat, } \\
\text { round shaped with dot-like } \\
\text { center, serrated edges, rough } \\
\text { surface, soft texture }\end{array}$ \\
\hline 3-IT & LAPTg10 agar & & $\begin{array}{l}1-2 \mathrm{~mm} \text { in diameter, whitish, flat, } \\
\text { round shaped, serrated edges, } \\
\text { rough surface, soft texture }\end{array}$ \\
\hline
\end{tabular}




\begin{tabular}{|c|c|c|c|}
\hline & MRS agar & & No growth \\
\hline & mMRS agar & & No growth \\
\hline & MSM agar & & $\begin{array}{l}\text { 1-4 mm in diameter, whitish, flat, } \\
\text { round or irregular shaped, } \\
\text { serrated edges, rough surface, } \\
\text { soft texture }\end{array}$ \\
\hline \multirow[t]{4}{*}{ 4-IT } & LAPTg10 agar & 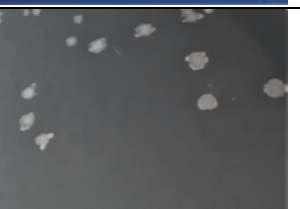 & $\begin{array}{l}\text { 1-6 mm in diameter, whitish, flat, } \\
\text { irregular shaped (snowflake-like) } \\
\text { with dot-like center, serrated } \\
\text { edges, rough surface, soft texture }\end{array}$ \\
\hline & MRS agar & $\because \because$ & $\begin{array}{l}1-2 \mathrm{~mm} \text { in diameter, whitish, flat, } \\
\text { round shaped, serrated edges, } \\
\text { rough surface, soft texture }\end{array}$ \\
\hline & mMRS agar & 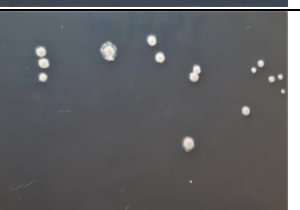 & $\begin{array}{l}1-4 \mathrm{~mm} \text { in diameter, whitish, flat, } \\
\text { round or irregular shaped, } \\
\text { serrated edges, rough surface, } \\
\text { soft texture }\end{array}$ \\
\hline & MSM agar & & $\begin{array}{l}\text { 2-6 mm in diameter, whitish, flat, } \\
\text { round or irregular shaped } \\
\text { (snowflake-like) with dot-like } \\
\text { center, serrated edges, rough } \\
\text { surface, soft texture }\end{array}$ \\
\hline \multirow[t]{4}{*}{ 5-IT } & LAPTg10 agar & $\begin{array}{c}\cdots \\
\cdots \\
\cdots\end{array}$ & $\begin{array}{l}1-2 \mathrm{~mm} \text { in diameter, whitish, flat, } \\
\text { round shaped, serrated edges, } \\
\text { rough surface, soft texture }\end{array}$ \\
\hline & MRS agar & 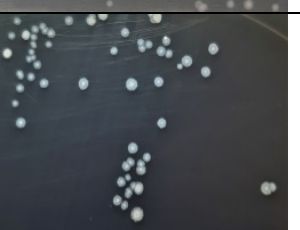 & $\begin{array}{l}1-2 \mathrm{~mm} \text { in diameter, whitish, flat, } \\
\text { round shaped with dot-like } \\
\text { center, serrated edges, rough } \\
\text { surface, soft texture }\end{array}$ \\
\hline & mMRS agar & 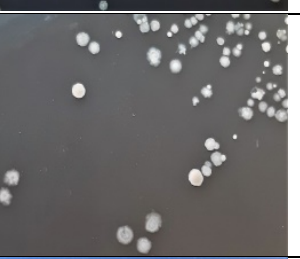 & $\begin{array}{l}\text { 1-3 } \mathrm{mm} \text { in diameter, whitish, flat, } \\
\text { round shaped, serrated edges, } \\
\text { rough surface, soft texture }\end{array}$ \\
\hline & MSM agar & $\begin{array}{l}\cdots \\
\therefore\end{array} \quad \because *$ & $\begin{array}{l}1-2 \mathrm{~mm} \text { in diameter, whitish, flat, } \\
\text { round shaped, serrated edges, } \\
\text { rough surface, soft texture }\end{array}$ \\
\hline
\end{tabular}




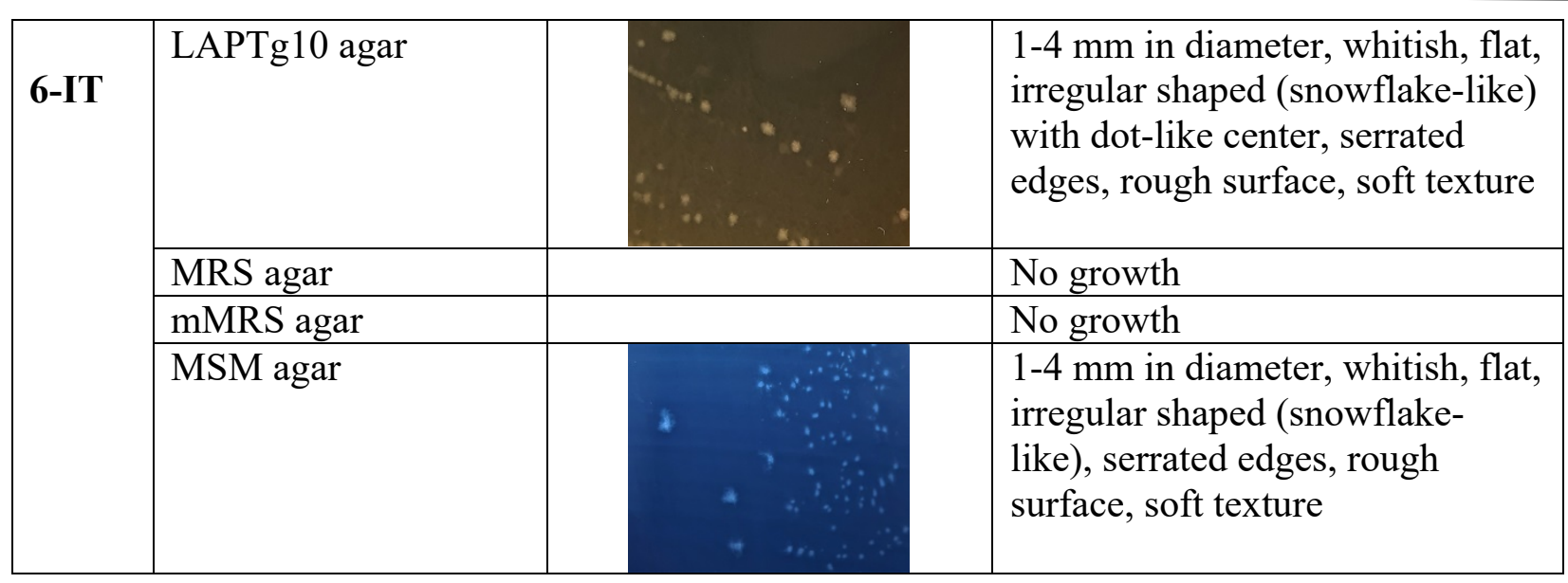

\subsection{Strain identification}

Besides the standard methods used for characterization, the species and strain identification require application of some rapid and reliable molecular genetic techniques such as polymerase chain reaction (PCR), amplified ribosomal DNA restriction analysis (ARDRA) and nucleotide sequencing.

The results obtained from conventional PCR amplification of 16S rDNA, followed by nucleotide sequencing and comparative $16 \mathrm{~S}$ rRNA gene sequence-based phylogenetic analysis revealed that all of the studied isolates belonged to the bacterial species Lactobacillus delbrueckii subsp. bulgaricus. The isolates exhibited 92\% (strain 5-BG), 97\% (strain 6BG) and 99\% (strains 1-BG, 3-BG, 7-BG, 8BG, 1-IT, 3-IT, 4-IT, 5-IT and 6-IT) pairwise similarity of the sequence of $16 \mathrm{~S}$ rDNA to the partial sequence of 16S rDNA of the relevant reference L. bulgaricus strains (Table 2).

Molecular genetic methods have been successfully applied in a number of previous studies related to the identification, genotyping and grouping of Lactobacillus strains isolated from different dairy and non-dairy fermented products (Andrighetto et al., 1998; Markiewicz et al., 2010; Denkova et al., 2012; Yu et al., 2015).

Table 2. Pairwise similarity of the sequences of $16 \mathrm{~S}$ rDNA of the isolated L. bulgaricus strains and the partial sequences of $16 \mathrm{~S}$ rDNA of the reference L. bulgaricus strains

\begin{tabular}{|c|c|c|c|c|}
\hline Isolate & Reference strain & Identity/similarity & Gaps & Strand \\
\hline 1-BG & $\begin{array}{c}\text { L. delbrueckii subsp. bulgaricus } \\
\text { IMAU40160 }\end{array}$ & $1398 / 1407(99 \%)$ & $3 / 1407(0 \%)$ & Plus/Plus \\
\hline 3-BG & $\begin{array}{c}\text { L. delbrueckii subsp. bulgaricus } \\
3641\end{array}$ & $1435 / 1445(99 \%)$ & $4 / 1445(0 \%)$ & Plus/Plus \\
\hline 5-BG & $\begin{array}{c}\text { L.delbrueckii subsp. bulgaricus } \\
\text { A320 }\end{array}$ & $967 / 1053(92 \%)$ & $15 / 1053(1 \%)$ & Plus/Minus \\
\hline 6-BG & $\begin{array}{c}\text { L. delbrueckii subsp. bulgaricus } \\
4640\end{array}$ & $707 / 731(97 \%)$ & $8 / 731(1 \%)$ & Plus/Plus \\
\hline 7-BG & $\begin{array}{c}\text { L. delbrueckii subsp. bulgaricus } \\
\text { LJJ }\end{array}$ & $1424 / 1434(99 \%)$ & $2 / 1434(0 \%)$ & Plus/Minus \\
\hline 8-BG & $\begin{array}{c}\text { L. delbrueckii subsp. bulgaricus } \\
4133\end{array}$ & $1423 / 1431(99 \%)$ & $1 / 1431(0 \%)$ & Plus/Plus \\
\hline
\end{tabular}


Tumbarski et al./ Carpathian Journal of Food Science and Technology, 2021, 13(1), 38-54

\begin{tabular}{|c|c|c|c|c|}
\hline 1-IT & $\begin{array}{c}\text { L. delbrueckii subsp. bulgaricus } \\
4119\end{array}$ & $1441 / 1449(99 \%)$ & $4 / 1449(0 \%)$ & Plus/Plus \\
\hline 3-IT & $\begin{array}{c}\text { L. delbrueckii subsp. bulgaricus } \\
3789\end{array}$ & $1436 / 1454(99 \%)$ & $8 / 1454(0 \%)$ & Plus/Plus \\
\hline 4-IT & $\begin{array}{c}\text { L. delbrueckii subsp. bulgaricus } \\
\text { KLDS1.1011 }\end{array}$ & $1410 / 1427(99 \%)$ & $6 / 1427(0 \%)$ & Plus/Minus \\
\hline 5-IT & $\begin{array}{c}\text { L. delbrueckii subsp. bulgaricus } \\
3913\end{array}$ & $1447 / 1458(99 \%)$ & $8 / 1458(0 \%)$ & Plus/Plus \\
\hline 6-IT & $\begin{array}{c}\text { L. delbrueckii subsp. bulgaricus } \\
4017\end{array}$ & $1419 / 1420(99 \%)$ & $0 / 1420(0 \%)$ & Plus/Plus \\
\hline
\end{tabular}

\subsection{Antimicrobial activity}

Antimicrobial activity is an important criterion for selection of starter and probiotic cultures as natural antagonists of food spoilage and pathogenic microorganisms (Georgieva et al., 2015).

The results demonstrated that Bulgarian $L$. bulgaricus strains were characterized by higher antimicrobial activity compared to the Italian strains, expressed mainly against Gram-positive bacteria (Table 3). L. bulgaricus strains 3-BG, 5-BG and 8-BG exhibited the highest antimicrobial activity inhibiting the growth of $S$. aureus ATCC 25923, L. monocytogenes NBIMCC 8632, L. ivanovii ATCC 19119, $L$. innocua ATCC 33090, E. faecalis ATCC 19433 and E. faecuim ATCC 19434. $L$. bulgaricus strains 3-BG and 8-BG were active also against Gram-negative $P$. aeruginosa ATCC 9027, P. vulgaris ATCC 6380 (only 8BG), S. enteritidis ATCC 13076, S. abony NTCC 6017 and E. coli ATCC 25922. Among Italian strains, $L$. bulgaricus 4-IT showed highest antimicrobial activity against all Grampositive bacteria used in the study, and Gramnegative S. enteritidis ATCC 13076 and S. abony NTCC 6017. The rest of the $L$. bulgaricus strains (1-BG, 6-BG, 7-BG, 1-IT, 3IT, 5-IT and 6-IT) demonstrated weak antimicrobial effect. None of $L$. bulgaricus strains inhibited the test microorganism Klebsiella sp.

In recent years, several studies have revealed the technological properties and probiotic characteristics of $L$. bulgaricus strains such as antimicrobial activity, nisin resistance, and antibiotic susceptibility. Akpinar et al. (2011) ascertained that 17 of

25 L. bulgaricus strains isolated from homemade yogurts possessed antimicrobial activity against Klebsiella pneumoniae, 16 of 25 were active against Bacillus cereus and Pseudomonas fluorescens, 18 of 25 were active against $L$. monocytogenes, 6 of 25 were active against $S$. aureus, 3 of 25 were active against Bacillus coagulans, and all of them inhibited the growth of E. coli.

In contrast, Erdogrul and Erbilir (2006) reported weak antimicrobial activity (inhibition zones $<12 \mathrm{~mm}$ ) of $L$. bulgaricus strain isolated from the probiotic dairy product against $E$. coli ATCC 8739, $S$. aureus ATCC 6538, $P$. aeruginosa ATCC 9027, Klebsiella pneumoniae ATCC 18833, Salmonella typhimurium ATCC 13311 and Enterobacter cloacae ATCC 13047. The strain was inactive against Bacillus subtilis. Georgieva et al. (2015) investigated antimicrobial activity of five $L$. bulgaricus strains isolated from homemade yogurts, and found that all isolates had significant inhibitory effect on all tested bacteria - S. aureus NBIMCC 3703, B. cereus NBIMCC 1085, and E. coli NBIMCC 3702. 
Table 3. Antimicrobial activity of the isolated L. bulgaricus strains

\begin{tabular}{|c|c|c|c|c|c|c|c|c|c|c|c|c|}
\hline \multirow[t]{2}{*}{ Test microorganism } & \multicolumn{11}{|c|}{ L. bulgaricus strains, inhibition zones (mm) } & \multirow{2}{*}{$\underset{*}{\text { Control }}$} \\
\hline & 1-BG & 3-BG & 5-BG & 6-BG & 7-BG & 8-BG & 1-IT & 3-IT & 4-IT & 5-IT & 6-IT & \\
\hline \multicolumn{13}{|l|}{ Gram $(+)$ bacteria } \\
\hline $\begin{array}{l}\text { S. aureus } \\
\text { ATCC } 25923\end{array}$ & $\begin{array}{c}8 \pm 0.15 * \\
*\end{array}$ & $13 \pm 0.21$ & $12 \pm 0.23$ & $8 \pm 0.17$ & - & $11 \pm 0.26$ & $8 \pm 0.11$ & $10 \pm 0.23$ & $9 \pm 0.12$ & $8 \pm 0.11$ & $8 \pm 0.17$ & $40 \pm 0.29$ \\
\hline $\begin{array}{l}\text { L. monocytogenes } \\
\text { NBIMCC } 8632\end{array}$ & - & $12 \pm 0.23$ & $12 \pm 0.25$ & $8 \pm 0.18$ & $8 \pm 0.12$ & $12 \pm 0.29$ & - & $8 \pm 0.15$ & $8 \pm 0.18$ & - & - & $38 \pm 0.27$ \\
\hline $\begin{array}{l}\text { L. ivanovii } \\
\text { ATCC } 19119\end{array}$ & $8 \pm 0.11$ & $10 \pm 0.2$ & $12 \pm 0.29$ & - & $10 \pm 0.23$ & $12 \pm 0.24$ & $10 \pm 0.26$ & $10 \pm 0.29$ & $10 \pm 0.24$ & $8 \pm 0.16$ & $10 \pm 0.2$ & $40 \pm 0.24$ \\
\hline $\begin{array}{l}\text { L. innocua } \\
\text { ATCC } 33090\end{array}$ & - & $11 \pm 0.24$ & $12 \pm 0.2$ & $8 \pm 0.16$ & $11 \pm 0.28$ & $13 \pm 0.2$ & $8 \pm 0.17$ & $10 \pm 0.21$ & $10 \pm 0.28$ & $8 \pm 0.13$ & $10 \pm 0.23$ & $40 \pm 0.22$ \\
\hline $\begin{array}{l}\text { E. faecalis } \\
\text { ATCC } 19433\end{array}$ & - & $10 \pm 0.22$ & $10 \pm 0.19$ & $10 \pm 0.27$ & $9 \pm 0.19$ & $12 \pm 0.22$ & $8 \pm 0.13$ & $9 \pm 0.14$ & $10 \pm 0.22$ & $8 \pm 0.18$ & $8 \pm 0.15$ & $37 \pm 0.2$ \\
\hline $\begin{array}{l}\text { E. faecuim } \\
\text { ATCC } 19434\end{array}$ & $8 \pm 0.14$ & $9 \pm 0.16$ & $8 \pm 0.18$ & $8 \pm 0.14$ & $9 \pm 0.2$ & $10 \pm 0.21$ & - & - & $8 \pm 0.16$ & - & - & $30 \pm 0.21$ \\
\hline \multicolumn{13}{|l|}{ Gram (-) bacteria } \\
\hline $\begin{array}{l}\text { P. aeruginosa } \\
\text { ATCC } 9027\end{array}$ & $8 \pm 0.12$ & $8 \pm 0.17$ & - & - & - & $8 \pm 0.18$ & - & - & - & - & - & $13 \pm 0.19$ \\
\hline $\begin{array}{l}\text { P. vulgaris } \\
\text { ATCC } 6380\end{array}$ & - & - & - & - & - & $11 \pm 0.25$ & - & - & - & - & - & $25 \pm 0.2$ \\
\hline $\begin{array}{l}\text { S. enteritidis } \\
\text { ATCC } 13076\end{array}$ & - & $9 \pm 0.14$ & $8 \pm 0.13$ & - & - & $10 \pm 0.22$ & $8 \pm 0.16$ & - & $8 \pm 0.19$ & $8 \pm 0.12$ & - & $32 \pm 0.25$ \\
\hline $\begin{array}{l}\text { S. abony } \\
\text { NTCC } 6017\end{array}$ & - & $11 \pm 0.25$ & $8 \pm 0.11$ & $8 \pm 0.15$ & - & $10 \pm 0.28$ & - & - & $8 \pm 0.14$ & - & - & $29 \pm 0.28$ \\
\hline $\begin{array}{l}\text { E. coli } \\
\text { ATCC } 25922\end{array}$ & - & $8 \pm 0.19$ & - & - & - & $8 \pm 0.15$ & - & - & - & - & - & $30 \pm 0.23$ \\
\hline $\begin{array}{l}\text { Klebsiella sp. (clinical } \\
\text { isolate) }\end{array}$ & - & - & - & - & - & - & - & - & - & - & - & - \\
\hline
\end{tabular}

*Ampicillin $(10 \mathrm{mg} / \mathrm{ml}) ;{ }^{* *}$ standard deviation $( \pm \mathrm{SD}) ; \mathrm{d}_{\mathrm{well}}=6 \mathrm{~mm}$ 


\subsection{Nisin resistance and minimal inhibitory} concentration (MIC)

In our study, nisin resistance test showed that 10 of a total of $11 \mathrm{~L}$. bulgaricus strains were highly sensitive to the action of nisin (MIC values varying from $0.078 \mathrm{mg} / \mathrm{ml}$ for $L$. bulgaricus 3-BG, 6-BG, 1-IT, 3-IT, and 4-IT to $0.156 \mathrm{mg} / \mathrm{ml}$ for L. bulgaricus 1-BG, 5-BG, 7BG, 8-BG, and 5-IT) with the exception of Italian strain $L$. bulgaricus 6 -IT which was resistant to nisin (Table 4).

Table 4. Nisin resistance of the isolated L. bulgaricus strains and minimal inhibitory concentration (MIC)

\begin{tabular}{|c|c|c|c|c|c|c|c|c|c|c|c|}
\hline \multirow{2}{*}{ Nisin } & \multicolumn{10}{|c|}{ L. bulgaricus strains } \\
\cline { 2 - 10 } & 1-BG & 3-BG & 5-BG & 6-BG & 7-BG & 8-BG & 1-IT & 3-IT & 4-IT & 5-IT & 6-IT \\
\hline $\begin{array}{c}\text { MIC, } \\
\text { mg/ } \\
\text { ml }\end{array}$ & 0.156 & 0.078 & 0.156 & 0.078 & 0.156 & 0.156 & 0.078 & 0.078 & 0.078 & 0.156 & $\begin{array}{c}\text { Resis } \\
\text { tant }\end{array}$ \\
\hline
\end{tabular}

Lactobacilli, in particular L. bulgaricus strains are essential for food fermentation processes and food preservation, whether they are part of the natural microflora of the products or added as starter cultures.

One of the advanced approaches in food biopreservation is the application of bacteriocins - peptides with antimicrobial activity produced by some $\mathrm{LAB}$ and members of genus Bacillus. Nisin (E-234) is a bacteriocin synthesized by Lactococcus lactis subsp. lactis, which is officially approved as a "Generally Recognized as Safe" (GRAS), and widely used as a food additive and biopreservative in the food industry. Nisin is known to possesses strong inhibitory activity against Gram-positive bacteria, including LAB (Tumbarski et al., 2018b). However, the application of bacteriocins can disrupt the fermentation by inhibiting the LAB. In this regard, the selection of $L$. bulgaricus strains resistant to nisin is of great importance for the technological process in the production of stable and high-quality fermented products.

Inhibitory effect of nisin and sensitivity of L. bulgaricus strains have been demonstrated in some previous studies. Durlu-Özkaya et al. (2007) examined the exopolysaccharide (EPS) production of $20 \mathrm{~L}$. bulgaricus isolates from homemade yogurt and raw milk, and the correlation between EPS production and sensitivity of the strains to bacteriophages and nisin. The authors found that L. bulgaricus strains with high EPS-producing capacity were resistant to phages and nisin, and concluded that they are perspective as starter cultures in commercial yogurt production. On the other hand, the antimicrobial activity of nisin against pathogenic microorganisms and $\mathrm{LAB}$ depends on the dosage and storage conditions. Benkerroum et al. (2002) stated that in yogurt with addition of nisin at a dose of $10 \mathrm{RU} / \mathrm{mL}$, no L. monocytogenes survived at 24-th hour of storage at refrigeration conditions $\left(7{ }^{\circ} \mathrm{C}\right)$. However, the pathogen survived 13 days of storage at the same temperature in the controls (without addition of nisin). The authors concluded that nisin inhibited the yogurt fermentation at concentration higher than 50 $\mathrm{RU} / \mathrm{mL}$, and recommended its application in lower doses in order to control the growth of $L$. monocytogenes, and to prevent the excessive acidification normally observed in the end of the storage life of yogurt. 


\subsection{Antibiotic susceptibility}

In addition to antimicrobial activity and nisin resistance, the antibiotic resistance is another substantial criterion for selection of appropriate functional strains. The results showed that Bulgarian L. bulgaricus strains were moderately sensitive (inhibition zones 7 $16 \mathrm{~mm}$ ) or resistant to most of the 24 antibiotics used in the screening (Table 5). The most resistant among the Bulgarian strains was L. bulgaricus 6-BG, which was insensitive to 13 of 24 antibiotics tested (bacitracin, penicillin, oxacillin, amoxicillin, tetracycline, doxycycline, gentamicin, amikacin, rifampin, clarithromycin, chloramphenicol, ciprofloxacin and nalidixic acid), followed by L. bulgaricus 1-BG, which was resistant to 10 antibiotics (penicillin, ampicillin, amoxicillin, tetracycline, gentamicin, amikacin, clarithromycin, chloramphenicol, novobiocin and norfloxacin). L. bulgaricus 3-BG was resistant to penicillin, ampicillin, tetracycline, lincomycin, novobiocin, ciprofloxacin, nalidixic acid and sulfamethoxazole/trimethoprim. L. bulgaricus 5-BG was resistant to bacitracin, penicillin, amoxicillin, vancomycin, tetracycline, gentamicin, rifampin and nalidixic acid. $L$. bulgaricus 8-BG exhibited resistance to piperacillin, vancomycin, cefuroxime, doxycycline, rifampin, erythromycin, clarithromycin and sulfamethoxazole/ trimethoprim, while L. bulgaricus 7-BG was resistant to 5 antibiotics - rifampin, lincomycin, tobramycin, novobiocin and norfloxacin. In contrast, Italian L. bulgaricus strains were sensitive to almost all of total of 24 antibiotics tested. L. bulgaricus 5-IT was resistant to ampicillin, levofloxacin and sulfamethoxazole/trimethoprim; L. bulgaricus 1-IT was resistant to levofloxacin and sulfamethoxazole/trimethoprim; L. bulgaricus 3-IT and L. bulgaricus 4-IT - to sulfamethoxazole/ trimethoprim; L. bulgaricus 6-IT - to levofloxacin.
The antibiotic susceptibility of $L$. bulgaricus strains varies widely. Georgieva et al. (2015) examined antibiotic susceptibility of five $L$. bulgaricus isolates to nine antibiotics, and found that all tested strains were susceptible toward ampicillin, gentamicin, erythromycin and tetracycline. The results reported by Erdogrul and Erbilir (2006) demonstrated that L. bulgaricus strain isolated from probiotic product was moderately sensitive to ampicillin, vancomycin, oxacillin, cephalothin, and cefodizime, but highly sensitive to tobramycin. Kyriacou et al. (2008) investigated the antibiotic resistance of $91 \mathrm{~L}$. bulgaricus strains isolated from different commercial Greek yogurts, and found that $97.8 \%$ from them were resistant to ciprofloxacin, $65.9 \%$ resistant to kanamycin, $62.6 \%$ resistant to amikacin, $1.1 \%$ resistant to vancomycin, and $1.1 \%$ resistant to bacitracin. 
Tumbarski et al./ Carpathian Journal of Food Science and Technology, 2021, 13(1), 38-54

Table 5. Antibiotic susceptibility of the isolated L. bulgaricus strains

\begin{tabular}{|c|c|c|c|c|c|c|c|c|c|c|c|c|c|}
\hline \multicolumn{3}{|c|}{ Antibiotic } & \multicolumn{11}{|c|}{ L. bulgaricus strains } \\
\hline & $\mu \mathrm{g} / \mathrm{disc}$ & $\mathbf{M A}^{* * * *}$ & 1-BG & 3-BG & 5-BG & 6-BG & 7-BG & 8-BG & 1-IT & 3-IT & 4-IT & 5-IT & 6-IT \\
\hline Bacitracin & $0.07 *$ & \multirow{8}{*}{ 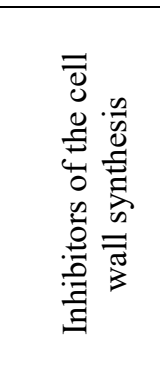 } & $\mathrm{S}$ & $\mathrm{S}$ & $\mathrm{R}$ & $\mathrm{R}$ & $\mathrm{S}$ & $\mathrm{S}$ & $\mathrm{S}$ & $\mathrm{S}$ & $\mathrm{S}$ & $\mathrm{S}$ & $\mathrm{S}$ \\
\hline Piperacillin & 100 & & SR & $\mathrm{S}$ & $\mathrm{S}$ & $\mathrm{S}$ & $\mathrm{S}$ & $\mathrm{R}$ & $\mathrm{S}$ & $\mathrm{S}$ & $\mathrm{S}$ & $\mathrm{S}$ & $\mathrm{S}$ \\
\hline Penicillin & $10^{*}$ & & $\mathrm{R}$ & $\mathrm{R}$ & $\mathrm{R}$ & $\mathrm{R}$ & SR & $\mathrm{S}$ & $\mathrm{S}$ & $\mathrm{S}$ & $\mathrm{S}$ & $\mathrm{S}$ & $\mathrm{S}$ \\
\hline Ampicillin & 10 & & $\mathrm{R}$ & $\mathrm{R}$ & SR & $\mathrm{S}$ & $\overline{S R}$ & SR & SR & $\mathrm{S}$ & SR & $\bar{R}$ & SR \\
\hline Oxacillin & 1 & & $\mathrm{~S}$ & SR & $\mathrm{S}$ & $\mathrm{R}$ & $\mathrm{S}$ & SR & $\mathrm{S}$ & $\mathrm{S}$ & $\mathrm{S}$ & SR & $\mathrm{S}$ \\
\hline Amoxicillin & 25 & & $\mathrm{R}$ & $\mathrm{S}$ & $\mathrm{R}$ & $\mathrm{R}$ & SR & $\mathrm{S}$ & $\mathrm{S}$ & $\mathrm{S}$ & $\mathrm{S}$ & $\mathrm{S}$ & $\mathrm{S}$ \\
\hline Vancomycin & 30 & & $\mathrm{~S}$ & $\mathrm{~S}$ & $\mathrm{R}$ & $\mathrm{S}$ & $\mathrm{S}$ & $\mathrm{R}$ & $\mathrm{S}$ & $\mathrm{S}$ & $\mathrm{S}$ & $\mathrm{S}$ & $\mathrm{S}$ \\
\hline Cefuroxime & 30 & & $\mathrm{~S}$ & $S$ & $\mathrm{~S}$ & $\mathrm{~S}$ & SR & $\mathrm{R}$ & SR & SR & $\mathrm{S}$ & $\mathrm{S}$ & $\mathrm{S}$ \\
\hline Tetracycline & 30 & \multirow{10}{*}{ 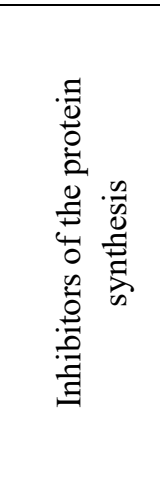 } & $\mathrm{R}$ & $\mathrm{R}$ & $\mathrm{R}$ & $\mathrm{R}$ & $\mathrm{S}$ & $\mathrm{S}$ & $\mathrm{S}$ & $\mathrm{S}$ & $\mathrm{S}$ & $\mathrm{S}$ & $\mathrm{S}$ \\
\hline Doxycycline & 30 & & $\mathrm{~S}$ & SR & $\mathrm{S}$ & $\mathrm{R}$ & $\mathrm{S}$ & $\mathrm{R}$ & $\mathrm{S}$ & $\mathrm{S}$ & $\mathrm{S}$ & $\mathrm{S}$ & $\mathrm{S}$ \\
\hline Gentamicin & 10 & & $\mathrm{R}$ & SR & $\mathrm{R}$ & $\mathrm{R}$ & S & $\mathrm{S}$ & $\mathrm{S}$ & S & S & S & S \\
\hline Amikacin & 30 & & $\mathrm{R}$ & $\mathrm{S}$ & $\mathrm{S}$ & $\mathrm{R}$ & $\mathrm{S}$ & $\mathrm{S}$ & $\mathrm{S}$ & $\mathrm{S}$ & SR & $\mathrm{S}$ & $S$ \\
\hline Rifampin & 5 & & SR & SR & $\mathrm{R}$ & $\mathrm{R}$ & $\mathrm{R}$ & $\mathrm{R}$ & $\mathrm{S}$ & $\mathrm{S}$ & $\mathrm{S}$ & $\mathrm{S}$ & S \\
\hline Lincomycin & 15 & & $\mathrm{~S}$ & $\mathrm{R}$ & SR & $\mathrm{S}$ & $\mathrm{R}$ & $\mathrm{S}$ & SR & $\mathrm{S}$ & $\mathrm{S}$ & $\mathrm{S}$ & SR \\
\hline Tobramycin & 10 & & SR & $\mathrm{S}$ & $\mathrm{S}$ & $\mathrm{S}$ & $\mathrm{R}$ & SR & SR & $S$ & SR & $\mathrm{S}$ & SR \\
\hline Erythromycin & 15 & & $\mathrm{~S}$ & SR & SR & $\mathrm{S}$ & SR & $\mathrm{R}$ & $\mathrm{S}$ & $\mathrm{S}$ & $\mathrm{S}$ & $\mathrm{S}$ & $\mathrm{S}$ \\
\hline Clarithromycin & 15 & & $\mathrm{R}$ & $\mathrm{S}$ & SR & $\mathrm{R}$ & SR & $\mathrm{R}$ & $\mathrm{S}$ & $\mathrm{S}$ & $\mathrm{S}$ & $\mathrm{S}$ & $\mathrm{S}$ \\
\hline Chloramphenicol & 30 & & $\mathrm{R}$ & $\mathrm{S}$ & SR & $\mathrm{R}$ & $\mathrm{S}$ & $\mathrm{S}$ & $\mathrm{S}$ & $\mathrm{S}$ & $\mathrm{S}$ & $\mathrm{S}$ & $\mathrm{S}$ \\
\hline Novobiocin & 5 & \multirow{6}{*}{ 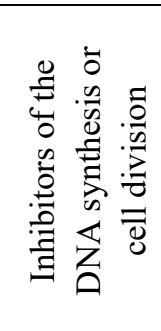 } & $\mathrm{R}$ & $\mathrm{R}$ & SR & SR & $\mathrm{R}$ & $\mathrm{S}$ & $\mathrm{S}$ & $\mathrm{S}$ & $\mathrm{S}$ & $\mathrm{S}$ & $\mathrm{S}$ \\
\hline Ciprofloxacin & 5 & & $\mathrm{~S}$ & $\mathrm{R}$ & SR & $\mathrm{R}$ & SR & $\mathrm{S}$ & SR & SR & $\mathrm{S}$ & $\mathrm{S}$ & SR \\
\hline Norfloxacin & 10 & & $\mathrm{R}$ & SR & SR & $\mathrm{S}$ & $\mathrm{R}$ & SR & SR & SR & $\mathrm{S}$ & $\mathrm{S}$ & SR \\
\hline Levofloxacin & 5 & & SR & SR & SR & $\mathrm{S}$ & SR & SR & $\mathrm{R}$ & $\mathrm{S}$ & $\mathrm{S}$ & $\mathrm{R}$ & $\mathrm{R}$ \\
\hline Nalidixic acid & 30 & & $\mathrm{~S}$ & $\mathrm{R}$ & $\mathrm{R}$ & $\mathrm{R}$ & SR & SR & SR & SR & SR & SR & SR \\
\hline $\begin{array}{l}\text { Sulfamethoxazole/ } \\
\text { Trimethoprim** }\end{array}$ & $\begin{array}{c}23.75 / \\
1.25\end{array}$ & & SR & $\mathrm{R}$ & $\mathrm{S}$ & $\mathrm{S}$ & SR & $\mathrm{R}$ & $\mathrm{R}$ & $\mathrm{R}$ & $\mathrm{R}$ & $\mathrm{R}$ & SR \\
\hline
\end{tabular}

${ }^{*} \mathrm{E} /$ disc; $* *$ - inhibits also the protein synthesis; $* * * \mathrm{MA}-$ mechanism of action; $\mathrm{R}$ - resistant; SR - intermediate (zone 7-16 mm); $\mathrm{S}-$ sensitive (zone $>16 \mathrm{~mm}) ; \mathrm{d}_{\mathrm{disc}}=6 \mathrm{~mm}$ 


\section{Conclusions}

In the present study, $11 \mathrm{~L}$. bulgaricus strains from traditional Bulgarian and Italian homemade yogurts were isolated and identified, and their antimicrobial activity, nisin resistance and antibiotic susceptibility were determined and compared. The antimicrobial screening demonstrated that Bulgarian $L$. bulgaricus strains were characterized by higher antimicrobial activity compared with the Italian strains, which was most pronounced in $L$. bulgaricus 3-BG, 5-BG and 8-BG. The results from nisin resistance test showed that only one of the isolates was resistant to nisin ( $L$. bulgaricus 6-IT). The antibiotic susceptibility test revealed that Bulgarian L. bulgaricus isolates were resistant or moderately sensitive to most of the antibiotics used, in comparison with the Italian strains, which were sensitive. The obtained results are important from a practical point of view, in the selection of suitable L. bulgaricus strains for use as starter cultures, probiotics, or in order to improve the food quality and safety. The future perspectives of the present research will be directed to further investigation of other probiotic and technological properties of the newly isolated L. bulgaricus strains, and development of technological schemes for their successful application in the composition of probiotic products.

\section{References}

Adolfsson, O., Meydani, S., Russell, R. (2004). Yogurt and gut function. The American Journal of Clinical Nutrition, 80, 245-56.

Akpinar, A., Yerlikaya, O., Kiliç, S. (2011). Antimicrobial activity and antibiotic resistance of Lactobacillus delbrueckii ssp. bulgaricus and Streptococcus thermophilus strains isolated from Turkish homemade yoghurts. African Journal of Microbiology Research, 5, 675-682.

Amara, S., Zadi-Karam, H., Karam, N.-E. (2019). Selection of Lactobacillus strains newly isolated from Algerian camel and mare fermented milk for their in vitro probiotic and lipolytic potentials. African Journal of Biotechnology, 18, 882-894.

Andrighetto, C., De Dea, P., Lombardi, A., Neviani, E., Rossetti, L., Giraffa, G. (1998). Molecular identification and cluster analysis of homofermentative thermophilic lactobacilli isolated from dairy products. Research in Microbiology, 149, 631-643.

Bauer, A., Kirby, W., Sherris, J., Turck, M. (1966). Antibiotic susceptibility testing by a standardized single disk method. American Journal of Clinical Pathology, 45, 493-496.

Benkerroum, N., Oubel, H., Sandine, W. (2002). Effect of nisin on yogurt starter, and on growth and survival of Listeria monocytogenes during fermentation and storage of yogurt. Internet Journal of Food Safety, 1, 1-5.

Chen, H.-Y., Li, X.-Y., Liu, B.-J., Meng, X.-H. (2017). Microencapsulation of Lactobacillus bulgaricus and survival assays under simulated gastrointestinal conditions. Journal of Functional Foods, 29, 248-255.

Danielsen, M., Wind, A. (2003). Susceptibility of Lactobacillus spp. to antimicrobial agents. International Journal of Food Microbiology, 82, 1-11.

Delley, M., Mollet, B., Hottinger, H. (1990). DNA probe for Lactobacillus delbrueckii. Applied and Environmental Microbiology, 56, 1967-1970.

Denkova, R., Yanakieva, V., Denkova, Z., Urshev, Z., Goranov, B., Sotirova, E. (2012). Identification and examination of some probiotic properties of Lactobacillus plantarum F3. Food and Environment Safety - Journal of Faculty of Food Engineering, Ştefan cel Mare University Suceava, 11, 22-29.

Durlu-Özkaya, F., Aslim, B., Taha Ozkaya, M. (2007). Effect of exopolysaccharides (EPSs) produced by Lactobacillus delbrueckii subsp. bulgaricus strains to bacteriophage and nisin sensitivity of the 
bacteria. LWT - Food Science and Technology, 40, 564-568.

Erdogrul, O., Erbilir, F. (2006). Isolation and Characterization of Lactobacillus bulgaricus and Lactobacillus casei from Various Foods. Turkish Journal of Biology, 30, 39-44.

Fisberg, M., Machado, R. (2015). History of yogurt and current patterns of consumption. Nutrition Reviews, 73, 4-7.

Georgieva, R., Yocheva, L., Tserovska, L., Zhelezova, G., Stefanova, N., Atanasova, A., Danguleva, A., Ivanova, G., Karapetkov, N., Rumyan, N., Karaivanova, E. (2015). Antimicrobial activity and antibiotic susceptibility of Lactobacillus and Bifidobacterium spp. intended for use as starter and probiotic cultures. Biotechnology \& Biotechnological Equipment, 29, 84-91.

Grigoroff, S. (1905). Étude sur une lait fermenté comestible. Le „Kissélo mléko“ de Bulgarie. Revue Médicale de la Suisse Romande, Genéve. Georg\&G., LibrairesÉditeurs. Librairie de L'Université.

Havenaar, R., Brink, B., Huis In't Veld, J. (1992). Selection of strains for probiotic use. In: Probiotics. Chapman \& Hall, Eds., 209-224.

Karapetkov, N., Georgieva, R., Rumyan, N., Karaivanova, E. (2011). Antibiotic susceptibility of different lactic acid bacteria strains. Beneficial Microbes, 2, 335-339.

Kyriacou, A., Tsimpidi, E., Kazantzi, E., Mitsou, E., Kirtzalidou, E., Oikonomou, Y., Gazis, G., Kotsou, M. (2008). Microbial content and antibiotic susceptibility of bacterial isolates from yoghurts. International Journal of Food Sciences and Nutrition, 59, 512-525.

Lane, D. (1991). 16S/23S rRNA sequencing. In: Nucleic acid techniques in bacterial systematics. Stackebrandt E. and Goodfellow M., Eds., John Wiley and Sons, New York, NY., 115-175.

Markiewicz, L., Biedrzycka, E., Wasilewska, E., Bielecka, M. (2010). Rapid molecular identification and characteristics of Lactobacillus strains. Folia Microbiologica, 55, 481-488.

McKinley, M. (2005). The nutrition and health benefits of yoghurt. International Journal of Dairy Technology, 58, 1-12.

Mohammed, S., D. Damisa, S. Oyeleke \& A. Jigam. (2013). Biopreservative efficiency of Lactobacillus bulgaricus FMB on Nono and Wara collected from Bosso metropolis - Niger state, Nigeria. Food Science and Technology, 14, 336-343.

Nwamaioha, N., Ibrahim, S. A. (2018). A selective medium for the enumeration and differentiation of Lactobacillus delbrueckii ssp. bulgaricus. Journal of Dairy Science, 101, 4953-4961.

Oyeniran, A, Ibrahim, S. A., Gyawali, R., Tahergorabi, R., Zimmerman, T., Krastanov, A. (2020). A modified reinforced clostridial medium for the isolation and enumeration of Lactobacillus delbrueckii ssp. bulgaricus in a mixed culture. Journal of Dairy Science, 103, 5030-5042.

Sanger, F., Nicklen, S., Coulson, A. (1977). DNA sequencing with chain-terminating inhibitors. In: Proceedings National Academy of Science, USA, 12, 5463-5467.

Silva, D., Sardi, J., Pitangui, N., Roque, S., da Silva, A., Rosalen, P. (2020). Probiotics as an alternative antimicrobial therapy: Current reality and future directions. Journal of Functional Foods, 73, 1-12.

Tabasco, R., Paarup, T., Janer, C., Peláez, C., Requena, T. (2007). Selective enumeration and identification of mixed cultures of Streptococcus thermophilus, Lactobacillus delbrueckii subsp. bulgaricus, $L$. acidophilus, L. paracasei subsp. paracasei and Bifidobacterium lactis in fermented milk. International Dairy Journal, 17, 1107-1114.

Teixeira, P. (2014). Lactobacillus. Lactobacillus delbrueckii ssp. bulgaricus. Encyclopedia of Food Microbiology, 425431. 
Tumbarski, Y., Lincheva, V., Petkova, N., Nikolova, R., Vrancheva, R., Ivanov, I., (2017). Antimicrobial activity of extract from aerial parts of potentilla (Potentilla reptans L.). Industrial Technologies, 4, 3743.

Tumbarski, Y., Deseva, I., Mihaylova, D., Stoyanova, M., Krastev, L., Nikolova, R., Yanakieva, V., Ivanov, I. (2018a). Isolation, characterization and amino acid composition of a bacteriocin produced by Bacillus methylotrophicus strain BM47. Food Technology and Biotechnology, 56, 546-552.

Tumbarski, Y., Lante, A., Krastanov, A. (2018b). Immobilization of bacteriocins from lactic acid bacteria and possibilities for application in food biopreservation. The Open Biotechnology Journal, 12, 2532.

Yu, J., Wang, H., Zha, M., Qing, Y., Bai, N., Ren, Y., Xi, X., Liu, W., Menghe, B., Zhang, H. (2015). Molecular identification and quantification of lactic acid bacteria in traditional fermented dairy foods of Russia. Journal of Dairy Science, 98, 5143-5154.

\section{Acknowledgment}

The authors declare no conflict of interests. 